\title{
COMMENT
}

\section{COVID-19 threat and the 1918 Spanish flu outbreak: The following day}

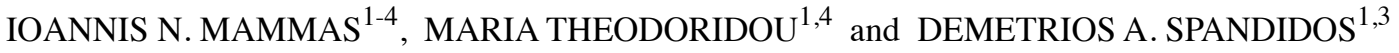 \\ ${ }^{1}$ Institute of Paediatric Virology; ${ }^{2}$ Paediatric Clinic, Aliveri, 34500 Island of Euboea; \\ ${ }^{3}$ Laboratory of Clinical Virology, Medical School, University of Crete, 71003 Heraklion; \\ ${ }^{4}$ First Department of Paediatrics, University of Athens School of Medicine, 11527 Athens, Greece
}

Received July 31, 2020; Accepted October 24, 2020

DOI: $10.3892 /$ etm.2020.9422

'Whatever was done, was done and nobody talks about it'

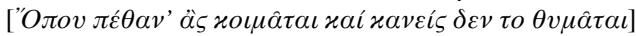

Constantinos Faltaits

Even though frontline paediatric care professionals seem to be unaffected by the current COVID-19 pandemic threat (1), they have been asked to deal with increased parental anxiety and uncertainty for the future. What will be the following day be like? If someone focuses on the 1918 Spanish flu global pandemic outbreak' lessons (2), then a realistic answer to this question could be proposed. On the Greek Aegean Sea island of Skyros, the pandemic outbreak was initiated at the end of October 1918 and out of its 3,200 residents, 1,000 individuals died of influenza in less than 30 days (3). The medical health care professionals of the island were among the first who died, each family had at least one lethal victim due to influenza despite they were isolated at their homes, while no medications or medical help or financial support from the central government was available on the island, at that time (3-5). The detailed description of each victim and family case by Constantinos Faltaits (1891-1921), a prominent Greek author and journalist of the last century, was really touching (3). Similar family cases have been reported in the nearby islands of Euboea and Andros (5-9). However, how was the following day of this pandemic tragedy of 1918 ?

Re-studying the report of 1919 by Constantinos Faltaits, which was written in Greek and remains unique in the whole Hellenic literature on the 1918 Spanish flu outbreak, the end of the pandemic on the island of Skyros could be divided into three phases. It was at the end of November 1918, just 30 days after the acute 'like a thunderbolt' and violent onset of the

Correspondence to: Professor Demetrios A. Spandidos, Laboratory of Clinical Virology, Medical School, University of Crete, 71003 Heraklion, Greece

E-mail: spandidos@spandidos.gr

Key words: COVID-19, SARS-CoV-2, 1918 Spanish flu outbreak, Skyros island, Greece outbreak and 'the deaths became four, three, and two every day, and voices of life and some movement started to be heard outside on the roads and few alive people at the beginning, and more and more later on, dared to go out of their homes, like those who had been saved from the Biblical Cataclysm. And later on, during the first days of December, without any more new deaths, the streets and the markets were full of old people again, who were coming out of their houses to feel the light of the Sun and learn about their relatives, their friends, to learn about what happened to the world' (3). People being enemies or hating each other 'from generation to generation wanted to hug each other and everybody, who had lost many or even only a few of their parents, their children, their brothers and sisters, women, men were comforting each other' full of happiness that they had managed to survive (3).

This initial phase was followed by 'grief and heartbreak' for all the influenza victims, who lost their lives so suddenly. Everybody began to look for the place where their relatives and friends had been buried, some of them asked to re-bury them and even they could not find them, 'they were choosing an empty monument, they were whitening its stones, they were building it putting a cross on the top and they were lightening a candle' to honor their memory (3).

During the third phase, life had returned back to its normal rhythm. 'Life continued with the same evils and passions, with the same pride, the same ugliness, the same beauty. People became again small or great, powerful or miserable, vile, humble, like the worms of the earth or the butterflies on the flowers, people were born on the island and raised by its air' (3). The near future will prove what the following day of the COVID-19 global pandemic will be like (10-16).

\section{Acknowledgements}

This article is published in the context of the foundation of the Institute of Paediatric Virology (IPV; https:// paediatricvirology.org) based on the island of Euboea (Greece), 
under the auspices of the World Academy of Sciences (WAS) and the support of the Department of Clinical Virology of the University of Crete School of Medicine and the First Department of Paediatrics of the University of Athens School of Medicine. We would like to thank all the members of the IPV for their valuable comments and corrections.

\section{Funding}

No funding was received.

\section{Availability of data and materials}

Not applicable.

\section{Authors' contributions}

INM, MT and DAS contributed equally to the conception and design of this manuscript, wrote the original draft, edited and critically revised the manuscript, read and approved the final manuscript.

\section{Ethics approval and consent to participate}

Not applicable.

\section{Patient consent for publication}

Not applicable.

\section{Competing interests}

INM, MT and DAS are co-founders of the Institute of Paediatric Virology (IPV). DAS is the Editor-in-Chief for the journal, but had no personal involvement in the reviewing process, or any influence in terms of adjudicating on the final decision, for this article.

\section{References}

1. Ludvigsson JF: Systematic review of COVID-19 in children shows milder cases and a better prognosis than adults. Acta Paediatr 109: 1088-1095, 2020.
2. Mammas IN, Theodoridou M and Spandidos DA: The 1918 Spanish flu outbreak that devastated a Greek island underlines past lessons that must never be forgotten. Acta Paediatr 107: 2034, 2018

3. Faltaits C: Influenza in Skyros, Annals. Vasileiou Editions, Athens, 1919 (In Greek).

4. Fragkoulis AI. Skyrian echos, 1959 (In Greek).

5. Mammas IN, Theodoridou M, Thiagarajan $P$, Melidou A, Papaioannou G, Korovessi P, Koutsaftiki C, Papatheodoropoulou A, Calachanis M, Dalianis T, et al: A paediatric influenza update 100 years after the Skyros island Spanish flu outbreak. Exp Ther Med 17: 4327-4336, 2019.

6. Chatiras T: History of East and South Euboea. Thucydides Editions, 1992 (In Greek).

7. Mammas IN, Theodoridou M and Spandidos DA: The 'Spanish' flu outbreak at the islands of Skyros, Euboea and Andros 100 years ago. Int J Mol Med 42: S22, 2018.

8. Mammas IN. The influenza in Port Buffalo in the island of Euboea: a family's reference. To Roptro 57: 62-66, 2019 (In Greek).

9. Mammas IN and Spandidos DA: A literature reference on the 1918 Spanish flu outbreak. Exp Ther Med 17: 4325-4326, 2019.

10. Docea AO, Tsatsakis A, Albulescu D, Cristea O, Zlatian O, Vinceti M, Moschos SA, Tsoukalas D, Goumenou M, Drakoulis N, et al: A new threat from an old enemy: Re-emergence of coronavirus. Int J Mol Med 45: 1631-1643, 2020.

11. Calina D, Docea AO, Petrakis D, Egorov AM, Ishmukhametov AA, Gabibov AG, Shtilman MI, Kostoff R, Carvalho F, Vinceti M, et al: Towards effective COVID-19 vaccines: Updates, perspectives and challenges. Int $\mathrm{J}$ Mol Med 46: 3-16, 2020.

12. Zoumpourlis V, Goulielmaki M, Rizos E, Baliou S and Spandidos DA: The COVID-19 pandemic as a scientific and social challenge in the 21st century. Mol Med Rep 22: 3035-3048, 2020.

13. Tsatsakis A, Calina D, Falzone L, Petrakis D, Mitrut R, Siokas V, Pennisi M, Lanza G, Libra M, Doukas SG, et al: SARS-CoV-2 pathophysiology and its clinical implications: An integrative overview of the pharmacotherapeutic management of COVID-19. Food Chem Toxicol 146: 111769, 2020.

14. Maltezou HC, Theodoridou K and Poland G: Influenza immunization and COVID-19. Vaccine 38: 6078-6079, 2020.

15. Lytras $\mathrm{T}$ and Tsiodras S: Lockdowns and the COVID-19 pandemic: What is the endgame? Scand J Public Health: doi: $10.1177 / 1403494820961293$.

16. Kostoff RN, Briggs MB, Porter AL, Aschner M, Spandidos DA and Tsatsakis A: COVID-19: Post-lockdown guidelines. Int J Mol Med 46: 463-466, 2020.

(i) $\Theta$ This work is licensed under a Creative Commons Attribution-NonCommercial-NoDerivatives 4.0 International (CC BY-NC-ND 4.0) License. 